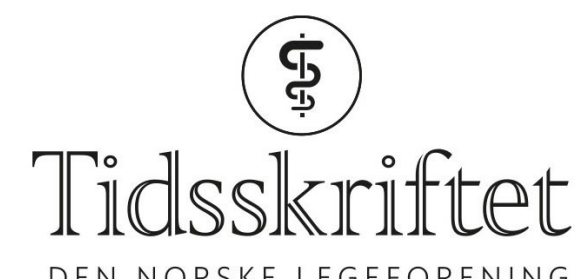

DEN NORSKE LEGEFORENING

\title{
Mondors sykdom
}

MEDISINEN I BILDER

\section{HEGE NORDLIE}

E-post: hegeja@vestreviken.no

Avdeling for bildediagnostikk

Drammen sykehus

Hege Nordlie (f. 1981) er lege i spesialisering.

Forfatter har fylt ut ICMJE-skjemaet og oppgir ingen interessekonflikter.

\section{ASE TANGERUD}

Avdeling for bildediagnostikk

Drammen sykehus

Åse Tangerud (f. 1957) er spesialist i radiologi og overlege.

Forfatter har fylt ut ICMJE-skjemaet og oppgir ingen interessekonflikter.

\section{SOLVEIG ELISE THORSNES}

Avdeling for bildediagnostikk

Drammen sykehus

Solveig Elise Thorsnes (f. 1991) var turnuslege i 2016-17.

Forfatter har fylt ut ICMJE-skjemaet og oppgir ingen interessekonflikter.

\section{STINE BREIVIK}

Avdeling for bildediagnostikk

Drammen sykehus

Stine Breivik (f. 1989) var turnuslege i 2016-17.

Forfatter har fylt ut ICMJE-skjemaet og oppgir ingen interessekonflikter.

En tidligere frisk kvinne i 6o-årene oppsøkte legevakten etter fire dagers sykehistorie med ubehag og ømhet under høyre bryst. Når hun beveget skulderen, strammet huden under brystet. Ved palpasjon kjentes en spent, subkutan streng som strakte seg vertikalt fra nedre del av høyre bryst til høyre side av abdomen i nivå med umbilicus. 


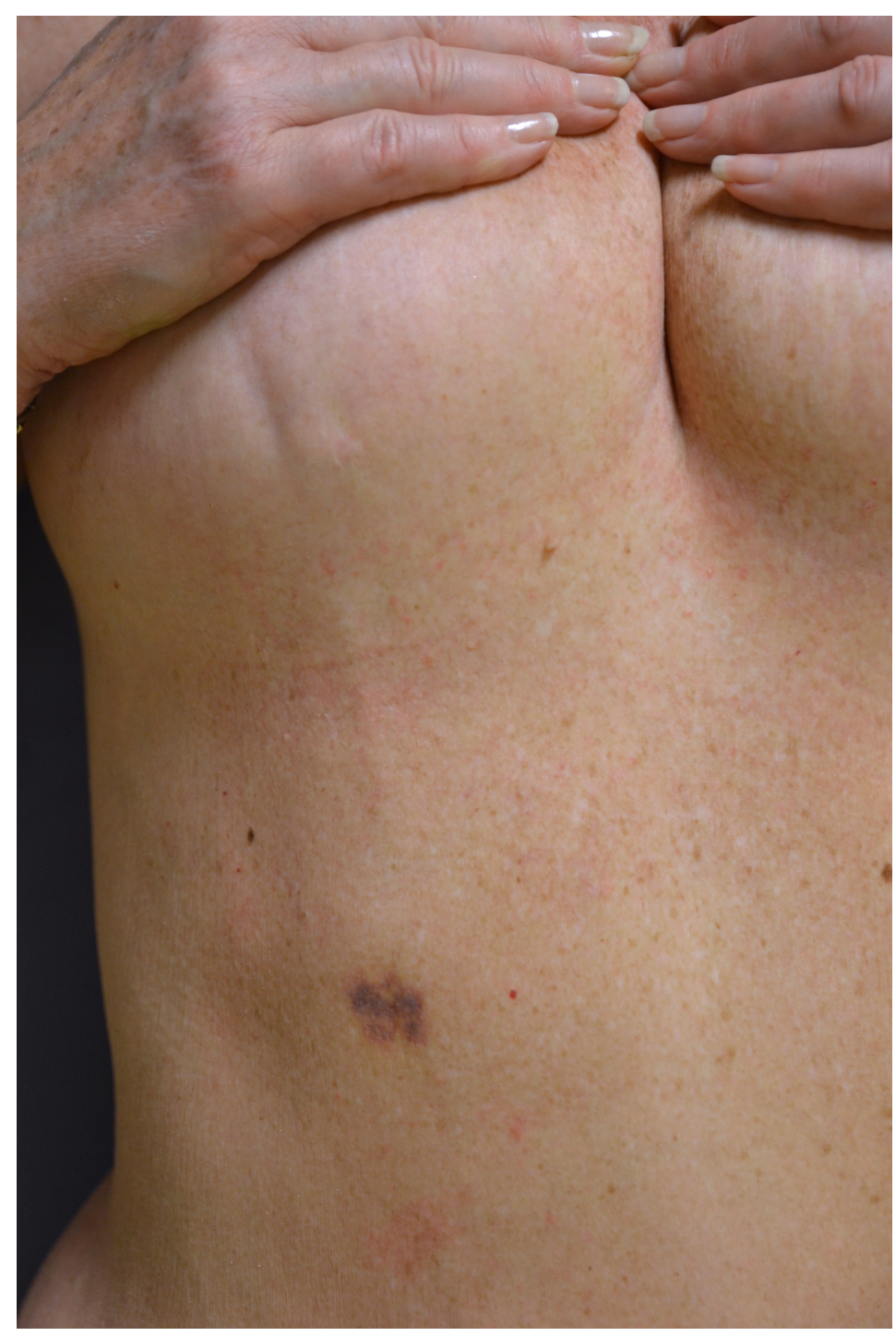

Da legevaktlegen palperte brystet, kjente pasienten at strengen røk. I ettertid fikk hun et lite, subkutant hematom på høyre side av abdomen. Strengen var fremdeles palpabel, men ikke lenger spent, og det hadde dannet seg en vertikal hudimpresjon kaudalt for høyre mamilla. Ved ultralydundersøkelse var det ikke mulig å fremstille strengen sikkert, men i enkelte tverrsnitt så man antydning til en $5 \mathrm{~mm}$ stor tubulær, homogen og lavtett struktur rett under hudoverflaten, med ekkogenisitet svært likt omliggende fettvev og med manglende dopplersignal.

Diagnosen Mondors sykdom ble stilt ut fra sykehistorie og kliniske funn.

Ultralydundersøkelse hadde i dette tilfellet begrenset verdi. Tilstanden ble behandlet konservativt, og det var tydelig bedring i både kliniske funn og symptomer i løpet av få dager.

Fotografiet viser den subkutane strengen i nedre del av høyre mamma og i nivå med umbilicus, en vertikal hudimpresjon i høyre mamma og det subkutane hematomet.

Mondors sykdom ble beskrevet av den franske kirurgen Henri Mondor i 1939. Det er en skleroserende, overflatisk tromboflebitt av de subkutane venene på anterolaterale bryst-og bukvegg (1). Tilstanden er sjelden - i litteraturen er det beskrevet ca. 500 tilfeller, stort sett rapportert som kasuistikker. Mulige risikofaktorer er traume, muskulær overanstrengelse, kirurgi, brystbiopsi (2), venøs kompresjon fra klær/bandasjer og intravenøs narkotikabruk.

Som hos vår pasient er det imidlertid i mange tilfeller ingen kjent utløsende årsak. Behandlingen er konservativ. Tilbakegang kan forventes i løpet av 1-2 måneder, og symptomene kan lindres med ikke-steroide antiinflammatoriske midler. Sammenhengen med brystkreft er uklar, men det bør være lav terskel for brystdiagnostikk ved klinisk mistanke eller kjente risikofaktorer for brystkreft. 
LITTERATUR:

1. Alvarez-Garrido H, Garrido-Ríos AA, Sanz-Muñoz C et al. Mondor’s disease. Clin Exp Dermatol 20o9; 34: 753 - 6. [PubMed][CrossRef]

2. Kibil W, Hodorowicz-Zaniewska D, Kulig J. Mondor's disease in a patient after a mammotome biopsy. Wideochir Inne Tech Malo Inwazyjne 2015; 10: 138 - 40. [PubMed][CrossRef]

Publisert: 18. mai 2018. Tidsskr Nor Legeforen. DOI: 10.4045/tidsskr.18.oog1 Mottatt 25.1.2018, godkjent 23.3.2018.

(C) Tidsskrift for Den norske legeforening 2020. Lastet ned fra tidsskriftet.no 